\title{
The Need Analysis of Maritime English Learning Materials for Nautical Students of Maritime Academy in Indonesia Based on STCW'2010 Curriculum
}

\author{
I Wy Dirgeyasa ${ }^{1}$ \\ ${ }^{1}$ Faculty of Languagaes and Arts, Universitas Negeri Medan, Indonesia \\ Correspondence: I Wy Dirgeyasa, English Language and Literature Department, Faculty of Languages and Arts, \\ Universitas Negeri Medan, Indonesia. Tel: 62-821-6213-0480. E-mail: wayandirgayasa@yahoo.com
}

Received: July 11, 2018 Accepted: August 7, 2018 Online Published: August 8, 2018

doi: 10.5539/elt.v11n9p41 URL: http://doi.org/10.5539/elt.v11n9p41

\begin{abstract}
This study was aimed to investigate the Maritime English learning materials needed by the students of nautical department of Maritime Academy in Indonesia based in STCW'2010 curriculum. The participants of the research were the seafarers, the port authorities, the shipping business employees, the English lecturers, and the cadets of Maritime Academy. They were totally about 48 participants. They were selected by using purposive random sampling technique. There were three types of instruments for collecting data those were questionaire, documentary sheet, and interview. The results of the study shows that 1) there were three basic leaning materials categories of Maritime English namely a) the nautical contents, b) language skills, and c) languistic features and 2) the level of needs of those materials were different from categories to another categories and within categories.
\end{abstract}

Keywords: maritime English, learning materials, STCW'2010 curriculum

\section{Introduction}

In the last three years, Indonesian government officially declared that the maritime world and industry became the national strategic policy. By this policy, the government made maritime axis or maritime toll road across the nation in order to increase a economic growth nationally (Kompas, 2014; Tempo, 2014).

To execute this policy, the supply of the seafarers having qualified professional competencies and communicative competency (English) is a must. Captain Salehudin, the port authority of Belawan states that nowadays, Indonesia needs 300-4000 professional seafarers each year (Waspada, 2016). Then, in the international scale, the demand of the seafarers reaches 93.900 persons the four years a head (Dirgayasa, 2014).

In Indonesian context, for Maritime Academy, as a Maritime Education and Training (MET), this reality becomes prospective opportunities and challange as well in order to produce the qualified seafarers having a good communication skill (English). By acquiring a good English skill, the seafarers are expected to be able to compete with other seafarers from the other countires across the globe. To actualize the professional seafarers having a good English, the MET must implement the Standard Training Certification Watchkeeping for Seafarers (STCW'95) curriculum and now is amanded to be STCW' 2010 (STCW' 2010 Amendments) here after (STCW'2010).

By STCW'2010, MET graduates across the world are required to have good standard of English competences either spoken or written form of communication. The implemention the STCW'2010 actually implicates three points. First, English subject is categorized as professional subject having similiar position and and role with other nautical subjects such as 'Celestial Naviagtion,' 'Ship handling,' 'Stability,' etc. Second, All subjects are tested use English language. Third, the diploma must be written in two languages-the English and the national language where the MET is setttled. Finally, by STCW'2010, all seafarers across the world have minimum and equal competence in English (Dirgayasa, 2014; Blakey, 1978; IMO, 1995; Bridge Procedure Guide, 1998).

Again, in Indonesia context, the alumni and the students of MET are not good at English either in the form of oral and written English. (ED-AMI Medan, 2010; Dirgayasa, 2014). In line with the low English competence, both the students and the alumni, Risuandi argued that the students and the alumni of MET still have low English proficiencies. Generally their English were lower than the almuni and students of MET from other countries 
(Indopos, 2009).

Theoritically and empirically, one of the main factors determining whether the learning is achieved or not is the learning materials. Katio (2009) stated that learning material is one of the important components in learning process. Learning materials provide the essence of the comptences which must be mastered and achived by the students. Unfortunately, the existing and the avaliability of the relevant Maritime English learning materials in accordance to the STCW'2010 curriculum is still rare and limited (Dirgayasa, 2015; Dirgayasa, 2014). Actually the scarcity of Maritime English materials or book becomes an international issue and reality. Pritchard (2009) claims that the real condition of existing materials of maritime academies are: (a) non-existence of standards on Maritime English syllabus, (b) lack of standards on Maritime English course books, (c) poor supply of textbooks for international use, and (d) lack of related learning resources, and e) restrictive national legislation and language policies.

Due to the lack of and scarcity of the Maritime English learning materials, the insufficiency, and the irrelevance of the existing Maritime English materilas for the nautical students, this study is to investigete the Maritime English learning materials in line with the Standard Training Certification (STCW'2010) by need analysis. Need analysis plays a significant role in providing the relevant materials needed by the students (Dirgayasa, 2015; Xiao, 2008; Corazon, 1995).

\section{Literature Review}

\subsection{The Nature of Maritime English}

It is generally known that the Maritime English (ME) is the most typical branch of English for Specific Purposes (ESP). It is really different form any other ESP branches such as English for Tourism, (ET), or English for Jurnalism (EJ) or English for Busisness (EB), etc. So what is actually the Maritime English? Normaizura (2018) states that "Maritime English is as a navigational and safety communications from ship to shore and vice versa, ship to ship , and on board ships must be precise, simple and unambiguous, so as to avoid confusion and error, there is a need to standardize the language used" (https://prezi.com).

In line with Nomaizura, the Maritime English is also defined in the following terms such as 1) it is the language used to communicate in all maritime-specific situations, on-board, ship to ship, and ship to shore, 2) it includes maritime-specific terminology - navigation, on-board operations, roles and responsibilities, health and safety, emergencies, 3) English which has been simplified for use by seafarers of all nationalities, 40 Maritime English has been codified by the International Maritime Organization (IMO) as Standard Marine Communication Phrases (SMCP), and 5) General English language skills need to be good enough to combine with SMCP to achieve consistent and clear communication at sea (https://www.slideshare.net).

In addition, International Maritime Organization (IMO), states that Maritime English is a codified English in such a unique and typical one. The uniqueness and typicalities of English is labelled as a Standard Marine Communication Phrases (SMCP). The IMO Standard Marine Communication Phrases (SMCP) has been compiled 1) to assist in the greater safety navigation and of the conduct of the ship, 2) to assist maritime training institutions in meeting the objectives mentioned, and 3) to standardize the language used in communication for navigation at sea, in port o standardize the language used in communication for navigation at sea, in port approaches, waterways and harbors, and on board vessel with multilingual crews.

\subsection{Standard Training Certification and Watchkeeping for Seafarers (STCW)}

Standardization, training, sertification, and qualification for seafarers in terms of the mastery of English (hereafter Maritime English), is a must and compulsary for the seafarers worldwide (IMO, 1995). This is done in order to enable the seafarers acquring the minimum standard of English proficiencies across the world. Without standardization, training, sertification, and qualification in terms of English, the seafarers will have different proficiencies and competences in English. In fact, the maritime industry and its typical characteristics are universal and English is used as a media for maritime communication internationally in which the safarerers working in international ship may come from any different countries with different English competencies, skills, and dialects.

Martime Academy or Maritime Education and Training (MET) in the world must implement the STCW curriculum so that the seafarers produced by the MET provide a minimum standard of English proficiencies and competences worldwide (IMO, 1995; International Chamber of Shipping, 1998). By the STCW'2010, the seafarers a cross the globe are expected to be able communicate effectively and substantially in the maritime world. Also the human error in communication can be minimized as much as possible.

Historically, the STCW developed and changed over times. Originally it was declared in 1978 and it was known 
as STCW'78. Due to the world wide rapid development of maritime industry and the need of English is a must for the seafarers, the STCW'78 was amanded in 1995, and then it was known as STCW'95. The last amandement and revision of STCW was done in 2010 and it is now called STCW'2010. This is done in order to respond and answer the rapid and complex change and circumstance of the maritime industry in the last five years (http:/www.imo.org.31/03/2015).

In short, the STCW' 2010 curriculum also requires the students to have knowledge of written and spoken English that is adequate to understand chart, nautical publication, meteorological information, message concerning the ship's safety and operation, and adequate skill to communicate with other ship and coast station, etc (IMO, 1995). The communications within the bridge team need to be understood properly. Communication among multilingual team members, and in particular with ratings, should be either in a language that is common to all relevant bridge team members (Blakey, 1978; IMO, 1995; Bridge Procedure Guide, 1998).

\section{Research Method}

The objective of this study is to find out Maritime English learning materials which are relevant with the Standard Training Certification (STCW)' 2010 curriculum. This study had been conducted in five Maritime Academy in Indonesia. They were Maritime Academy Indonesia Medan (AMI-Medan) North Sumetara, Academy Maritime Sapta Samudra Padang, West Sumatera, Maritime Academy Djadjat Jakarta, Maritime Academy Yogyakarta (AMY-Yogyakarta) Yogyakarta, and Maritime Academy Makasar (MAM-Makassar) South Sulawesi.

\subsection{Participants}

The participants of the research were the seafarers, the port authorities, the shipping business employees, the English lecturers, and the cadets of Maritime Academy. They were totally about 48 participants. They were selected by using purposive random sampling. The composition of the participants were 8 peope from worldwide seafarers, 8 people from shipping business employees, 4 people from port authorites, 8 people from English lecturers, and from cadets of Maritime Academy reach were about 20 people. The distribution of the participants background is shown in the following Figure 1.

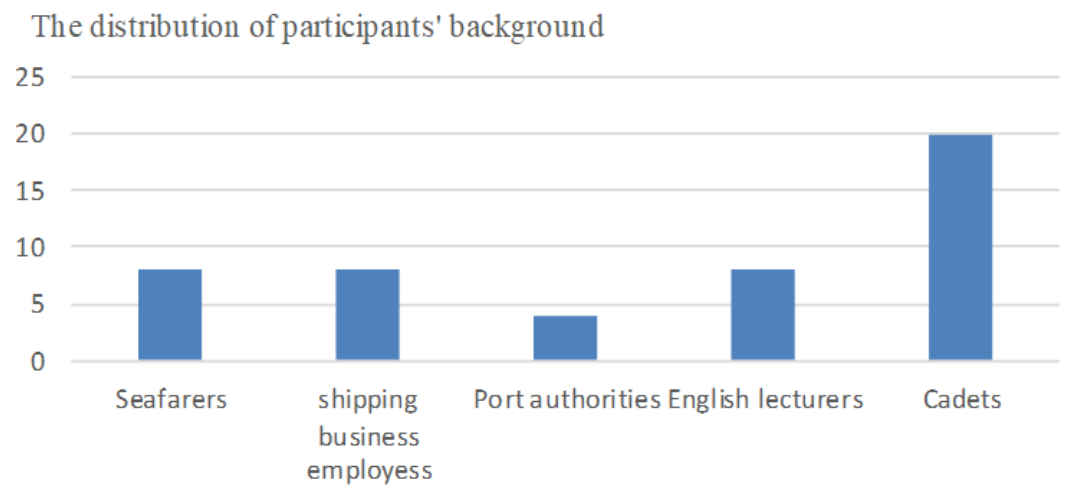

Figure 1. The distribution of participants' background

\subsection{Instrument for Collecting Data}

The instruments are developed to find out Maritime English materials which are relevant with the Standard Training Certification (STCW)' 2010 curriculum. There were three types of instruments for collecting data those were questionaire, documentary sheet, and interview. The questionaire consisted of five levels of need regarding to the need of the Maritime English Materials. The questionaire consisted of five scores ranging from (0-4). The scores reflect the levels of need were 1) very needed, 2) need, 3) fairly need, 4) less needed, and 5) not needed.

\subsection{Data Analysis}

Descriptive statisitics is generated to analyze the data. The data are displayed based on the leve of need as shown by Table 1 below. 
Table 1. The level of needs of maritime English materials

\begin{tabular}{lll}
\hline No & Score & Level of needs \\
\hline 1 & $0-0.5$ & Not needed \\
2 & $0.6-1.5$ & Less needed \\
3 & $1.6-2.5$ & Fairly needed \\
4 & $2.6-3.5$ & Needed \\
5 & $3.6-4.0$ & Strongly needed \\
\hline
\end{tabular}

Hatim (2000) in Dirgayasa (2014b).

\section{The Result and Discussion}

Based on the data collection, the data of Maritime English learning materials are classified into three basic materials of Maritime English learning materials that is a) the nautical contents, b) language skills, and c) languistic features.

\subsection{The Nautical Contents}

Based on the data collected, there are a number of various topics of nautical contents or content areas needed by the students in line with the STCW'2010 curriculum. However, those topics are distributed in different level of needed ranging from a) strongly needed, b) needed, c) farily needed, d) less needed, and e) not needed. Table 2 below shows the distribution topics dealing with natuical contents.

Table 2. The level of needs nautical contents of maritime English materials

\begin{tabular}{llll}
\hline No & Topics of nautical contents & Score & Level of need \\
\hline 1 & Describing crew and routine & 2.7 & Needed \\
2 & Naming types of vessels and their parts & 2.8 & Needed \\
3 & Ship construction & 3.0 & Needed \\
4 & Navigational routes and geograpical location & 3.7 & Strongly needed \\
5 & Describing how main engine work & 1.5 & less needed \\
6 & Nautical direction & 3.6 & Strongly needed \\
7 & Standard helm order & 3.8 & Strongly needed \\
8 & Standard engine order & 1.4 & Less needed \\
9 & Life saving equipments & 2.6 & Needed \\
10 & Ship system and stability & 3.6 & Strongly needed \\
11 & Visual communication & 3.7 & Strongly needed \\
12 & Nautical measurement & 3.6 & Strongly needed \\
13 & Weather & 3.4 & Needed \\
14 & Cargo handling and storage & 3.0 & Fairly needed \\
15 & Maintenance and repair & 1.2 & Fairly needed \\
16 & Navigation instruments and equipment & 3.8 & Strongly needed \\
17 & Firefighting & 2.6 & Needed \\
18 & Auxiliary enginees & 1.0 & Less needed \\
19 & Canvas and painting & 2.7 & Fairly needed \\
20 & Marlinespike & 2.8 & Fairly needed \\
21 & Log books & 2.9 & Needed \\
22 & Manouevring & 3.7 & Strongly needed \\
23 & Distress communication & 3.8 & Strongly needed \\
24 & Vessel Traffic Service (VTS) & 3.7 & Strongly needed \\
25 & Piloting and tug & 3.00 & Needed \\
26 & Ship construction & 2.6 & Needed \\
\hline
\end{tabular}

Table 2 above shows that of the 26 topics of nautical contents, the levels of needs are not proportionally distributed. About 10 topics or (38.46\%) such as navigational ruotes geograhical location, standard helm order, 
ship system and stability, visual communication etc are strongly needed by the students. Those eights topics becomes important topics mastered by the nautical students because those topics are frequently used on board (IMO, 1995); (Sheppard, Evans, \& Dooley, 2013).

While $34.61 \%$ of topics including firefighting, log books, weather, life saving equipments, etc are categorized needed by the students. Then, about four topics or (15.38\%) the results of research address topics such as marlinespike, cargo handling and storage, and maintenance and repair are classified as fairly needed by the students. Then, the topics categorized less needed include, auxiliary enginees, standard engine order, describing how main engine workm are less needed. It reaches only about (11.58\%) of the total content area topics. This happens because it seems that those topics are more relevan to the engineering students (engine officers) rather than the nautical students (deck officers) (Blakey, 1978); (Sheppard, Evans, \& Dooley, 2013).

In short the distribution of level of need of Maritime English materials is clearly shown in the figure below.

\section{Level of need of Maritime English Materials}

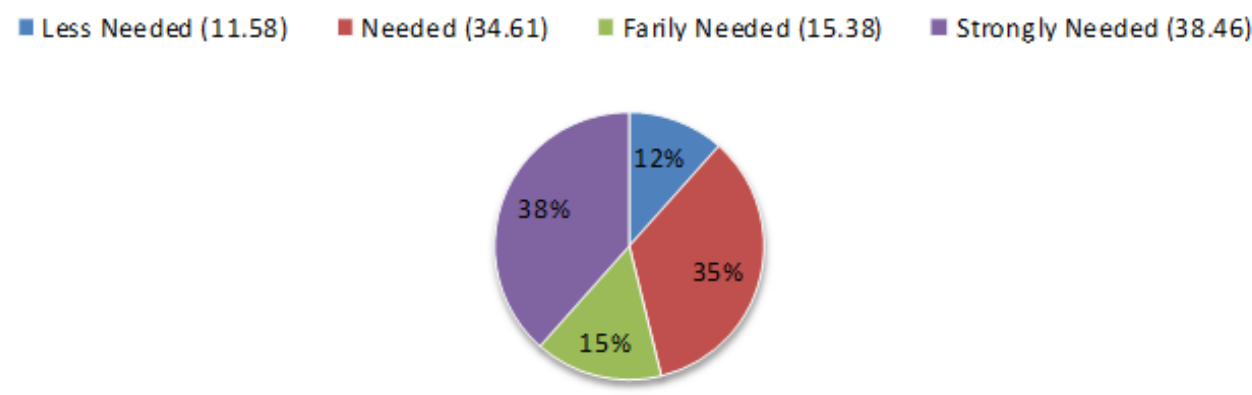

Figure 2. Level of need of maritime English materials

\subsection{Language Skills}

In terms of language skills, listening-speaking are strongly needed by the students. While reading skill is also important because reading is needed by the students. The complete data of level of need of language skills needed by the students is shown by table 3 below.

Table 3. The level of needs of language skilss

\begin{tabular}{llll}
\hline No & Language Skills & Score & Level of need \\
\hline 1 & Listening-speaking & 3.8 & Strongly needed \\
2 & Reading & 3.2 & Needed \\
3 & Writing & 2.5 & Needed \\
\hline
\end{tabular}

As stated in the STCW'2010 and IMO (1995), the nautical students when they work in the ship they are more intensively and frequently interacting and communicating on board (Norton \& Knutsen,1978). That is why the listening and speaking skills strongly needed. Then, reading skill is also important for the students. The reading skill is needed when they work on board. The need of reading skill is also in line with what is amanded in International Chamber of Shipping. Bridge Procedure Guide (1998) stated that reading is neccessary for the seafarers when they work on board. They need to understand the manual book, log book, nautical almanac, nautical chart, etc. In line reading content area, Xiao (2008) adds that the students also need topics about weather reports, Admiralty Notices to Mariners, Legends and Cautionary Notes on Navigational Charts, Sailing Directions, Guide to Port Entry and some international conventions and regulations such as International Regulations for Preventing Collision at Sea, International On-board Pollution Prevention; some navigational equipment instruction manuals and contracts or agreements.

Writing skill is also needed by the students. The topics or content area of writing need by the studens include drafting sea protest, sign some receipts, filling shipping documents and some application forms for port entry, port clearance, cargo handling, and log book Xiao (2008). Eventhough, the need of writing skill is also necessary 
for the students when they work on board but the intensivity and frequencies of writing work is quite rare. This happens because the jobs relating to writing domain are quiete limited on board. Generally the writing works are done by the seafarers at the management level. On board, the number of the the management level officers are limited.

\subsection{Language Linguistic Features and Translation}

As it is generally known that that Maritime English is a codified English in such a unique and typical one. The results of the research show that the linguistics features of Maritme English needed by the students classified into three main categories that is a) grammar, b) applied terminology, and c) Standard Marine Communication Phrases (SMCPs). Based on the result of the reseaarch, the need the three main lingusitic features are as follows; a) the need of grammar is needed, the need of applied terminolgoies relating to the maritime world is very needed, and the need of SMCPs is also categorized very needed. Besides, those linguistic features, translation comptence is also needed by the students. It is actually not suprising because the activity or process of translation is quite intensive and frequent done on board ship. Table 4 shows the detail of of level needs of linguistics features and transalation by scores.

Table 4. The level of needs of linguistic features

\begin{tabular}{llll}
\hline No & Linguistic features & Score & Level of need \\
\cline { 2 - 4 } 1 & Grammar & 3.00 & Needed \\
2 & Applied terminologies & 4.00 & Needed \\
3 & SMCPs & 4.00 & Strongly needed \\
4 & Translation & 3.8 & Strongly needed \\
\hline
\end{tabular}

By grammar, the topics needed by the students are relatively limited such tenses (present continutes, present, present perfect, past tense, past perfect, and future tense), pasive voice, quanitity, change verb, etc. While topic including the applied terminologies cover type of ropes, names of ship, parts of ships, names weather, names of fire extinguishers, etc. While the SMCPs have already become a standard of maritime communication used by seafarers when they communicate on board (within ship), between ship, with a shore, and even with helicopter IMO (1995); (Sheppard, Evans, \& Dooley, 2013). The SMCPs have already officially designed and codified in such way so that all people with different background of language competence and culture working in maritime industry must be familiar with and understand them. Then, Choi (2016) adds that the importance of clear and effective communication at sea has been greatly emphasized due to an increased trend of multiculturalism on board both ocean-going and coastal vessels, the necessity of systematic English training based on 'Knowledge, Understanding, and Proficiency' specified in STCW has been also recognized.

Besides, the translation competence is also needed by the students. Translation activities are quite often done by the seafarers when they work on board. The translation text may range from simple text such words, phrases, sentences, text or longer text, manual books, log book, etc. In short, translation is also often done in Maritime English language testing. Also, the translation is often used as one of the materials tested for having the diploma (Directorate General of Sea Transportation of Department of Transportation Indonesia, 2008).

\section{Conclusion}

The role of need analysis in any learning materials development is important and indisputable including the learning material of Maritime English. It becomes more relevant and improtant because the Maritime English is the most typical and unique among the English for Specific Purposes. By conducting the need analysis involving many relevant stakeholders as the sources of information and data, the Maritime English learning materials provided match with the needs of students and the STCW'2010 curriculum.

The need analysis has provided many, various, and different topics needed by the students of Maritime Academy such as vessel traffic service, ship handling, emergency on board, standard helm order, SMCps, types of rope, parts of vessel, reading, writing, limited and particular grammatical patterns, applied terminologies, etc. Those various and different topics of learning materials of Maritime English materials actually can be classified into three main categories that is a) the nautical contents or content areas, b) language skills and c) the linguistic features and transalation. Then, also in terms of level of needs of those learning materials are ranging froma strongly needed up to less needed. 


\section{References}

Akademi Maritim Indonesia Medan (AMI-Medan). (2010). Evaluasi Diri (Self-Evaluation). Medan.

Balabar, C. (1995). Collaborating with Subject Specialists. In H. C. Araceli (Ed.), Getting Started Materials Writer on Materials Writing. Singapore: SMEAO Publishing.

Blakey, T. N. (1978). English for Maritime Studies. London: Pregamon Press.

Choi, S. H. (2016). Considerations Regarding the Application of IMO Maritime English Model Course 3.17 in Korean Contexts. Procceding in International Maritime English Conference IMLA-IMEC, 28, 19-22.

Directorate General of Sea Transportation of Department of Transportation. (2008). The Framework Quality Standard System for MET in Indonesia. Jakarta.

Dirgeyasa. I. Wy. (2009). The Nature of Maritime English and Its Current Issues in Proceeding. CONNEST 6. Unika Atmajaya Jakarta.

Dirgeyasa. I. Wy. (2014). Survey of English Teaching and Learning Process in Maritime Education and Training in Indonesia: A case study in Private MET in Indonesia. English Language Teaching, 7(7).

Dirgeyasa. I. Wy. (2015). The Need Analysis of Maritime English Writing Materials through Genre Based Approach for Maritime Education and Training Students in Indonesia Proceeding in The 62nd TEFLIN International Conference. Denpasar Bali.

Indonesia Shipping Gazette. (2006). Media Perkapalan Indonesia.Jakarta, Juni.

International Maritime Organization. (1995). IMO Standard Marine Communication Phrases. London: Albert Embankment.

International Chamber of Shipping. (1998). Bridge Procedure Guide (3rd ed.). London: Marisac Publication.

Kitao, K. (1997). Selecting and Developing Teaching and Learning Materials. Retrieved from http//itselj.org/Article/Kitao-Materials.html/7/26/2009.

Norton, A. A., \& Knutsen, W. E. (1978). The Language of the Merchant Marine in English. New York: Regent Publishing Company, Inc.

Risuandi, Y. (2009). Dunia Memerlukan 83.900 Pelaut Internasional dalam IndoPos, Jakarta Edisi Kamis 20 Agustus.

Shipping, G. (2008). Media Perkapalan Indonesia. Jakarta.

The Nautical Institute. (1997). The Mariner's Roles in Collecting Evidence. London. The Nautical Institute.

Trenkner, P., \& Cole, C. (2009). Profiling the Maritime English Instructor-Are We All At Sea? Retrieved from http://www.iamu-edu.org/journal/5/trenkner-cole.php/7/26/2009/

Yang, S. C. (2000). A Relationship Study of English Learning Strategies, Learning Styles and English Proficiency. Proceedings of the National Science Council. Part C, Humanities and Social Sciences, I, $35-59$.

\section{Copyrights}

Copyright for this article is retained by the author(s), with first publication rights granted to the journal.

This is an open-access article distributed under the terms and conditions of the Creative Commons Attribution license (http://creativecommons.org/licenses/by/4.0/). 